\title{
A focus on the role of Pax4 in mature pancreatic islet $\beta$-cell expansion and survival in health and disease
}

\author{
Thierry Brun and Benoit R Gauthier \\ Department of Cell Physiology and Metabolism, University Medical Centre, 1211 Geneva 4, Switzerland \\ (Correspondence should be addressed to T Brun; Email: thierry.brun@medecine.unige.ch; B R Gauthier; Email: benoit.gauthier@medecine.unige.ch)
}

\begin{abstract}
Blood glucose homeostasis is achieved by the regulation of insulin and glucagon secretion from the pancreatic islet $\beta$ - and $\alpha$-cells. Diabetes mellitus, which comprises a heterogeneous group of hyperglycaemic disorders, results mainly from inadequate mass and function of islet $\beta$-cells. Autoimmune destruction of $\beta$-cells causes type 1 diabetes, while type 2 is characterized by impaired insulin secretion and is often associated with diminished insulin action on its target tissues. Interestingly, similar to type 1 diabetes, a gradual loss of $\beta$-cell mass is observed in type 2 diabetes often requiring insulin therapy. Understanding the molecular mechanism that governs $\beta$-cell mass plasticity may provide a means to develop strategies to countera,ct $\beta$-cell death while increasing replication. Of particular interest is the islet-specific transcription factor paired box4 ( $\mathrm{Pax} 4$ ) that was previously shown to be indispensable for the establishment of the $\beta$-cell lineage during development. However, recent accumulating evidence now suggest that Pax4 is also crucial for mature $\beta$-cell expansion and survival in response to physiological cues and that mutations or polymorphisms are associated with both type 1 and type 2 diabetes. In contrast, aberrant expression of Pax4 confers protection against apoptosis to insulinomas, whereas it promotes cell growth in lymphocytes. This review summarizes promising new published results supporting the important function of Pax4 in mature islet $\beta$-cell physiology and its contribution to pathophysiology when deregulated.
\end{abstract}

Journal of Molecular Endocrinology (2008) 40, 37-45

\section{Introduction: diabetes, obesity and pancreatic islet plasticity}

Plasma glucose levels are regulated by the action of insulin, a hormone that is produced and secreted by the pancreatic islet $\beta$-cells in response to nutrients. Diabetes mellitus, which comprises a heterogeneous group of hyperglycaemic disorders, results from inadequate mass and function of $\beta$-cells (Prentki \& Nolan 2006). In 2007, over 200 million people were diagnosed with diabetes mellitus and it is now considered one of the most common non-communicable diseases in the world causing $5 \%$ of all deaths per year (www.eatlas.idf.org). Alarmingly, the World Health Organization predicts that this will reach epidemic proportions with at least 366 million people afflicted with the disease by 2030 (www.who.int/dietphysicalactivity/publications/facts/diabetes/en). Diabetes mellitus was recently reclassified into three main entities: 1) type 1 diabetes which is linked to selective autoimmune destruction of pancreatic $\beta$-cells, 2) type 2 diabetes which is a severe disease of intermediary metabolism usually caused by both $\beta$-cell dysfunction and resistance to the biological actions of insulin on its main target tissues (liver, muscle and adipose) and 3) gestational diabetes mellitus (GDM) which is characterized by glucose intolerance with onset or first recognition during pregnancy (Bell \& Polonsky 2001, Saltiel \& Kahn 2001, Expert Committee on the Diagnosis and Classification of Diabetes Mellitus 2003, Stumvoll et al. 2005, Shaat \& Groop 2007). Long-term complications of diabetes include retinopathy and nephropathy as well as cardiovascular and cerebrovascular symptoms. Current therapy for type 2 diabetes and GDM include modification of lifestyle, such as diet and exercise, and the use of pharmacological agents that stimulate insulin secretion, decrease hepatic glucose production and increase sensitivity of target tissues to insulin. Nonetheless, often type 2 diabetic patients, like type 1 diabetics, require insulin therapy (Donath \& Halban 2004).

The phenomenal rise in the incidence of diabetes is predominantly attributable to its close association with development of obesity. Indeed, $\sim 60 \%$ of all cases of type 2 diabetes are directly linked to overweight due to shifting dietary habits and increasingly sedentary 
lifestyles of humans (Yach et al. 2006). Studies in animal models have demonstrated that obesity-associated insulin resistance as well as increased insulin requirements during pregnancy is matched by a corresponding stimulation in insulin output through $\beta$-cell hyperplasia and hypertrophy. For instance, rat pancreatic $\beta$-cell numbers transiently increase by $50 \%$ during pregnancy before returning to normal levels post partum (Scaglia et al. 1995). This $\beta$-cell plasticity reaches remarkable levels in Zucker diabetic fatty $(f a / f a)$ rats in which a fourfold increase in islet mass is observed with progression of obesity (Unger 2005). A similar increase in islet volume was shown in $o b / o b$ mice when compared with control animals (Bock et al. 2003). The expansion of $\beta$-cell mass is also observed in human obesity as well as in pregnancy, the latter most likely mediated by increased circulating placental lactogen and prolactin (Kloppel et al. 1985, Brelje et al. 1993, Sorenson \& Brelje 1997, Butler et al. 2003). Interestingly, up to $20 \%$ of obese individuals develop type 2 diabetes probably caused by a defective $\beta$-cell adaptation due to increased sensitivity to harmful environmental factors such as free fatty acids combined with predisposing genetic factors (Kashyap et al. 2003). The latter emphasizes that overall $\beta$-cell mass adaptation in response to physiological as well as to pathophysiological conditions is not only governed by the generation of new insulin-producing cells but also by susceptibility to cell death. In the extreme such as in type 1 diabetes, autoimmunemediated cell destruction is greater than the rate of regeneration leading to hyperglycaemia and invariably requiring insulin therapy. However, in rare cases, spontaneous remission characterized by increased C-peptide secretion has been reported in type 1 diabetic patients, clearly indicating the capacity of $\beta$-cell regeneration to prevail over autoimmune annihilation (Bonfanti et al. 1998). Fundamental mechanisms governing $\beta$-cell replenishment remain to be identified. In this review, we discuss the potential role of the transcription factor paired box4 (Pax4) as a key player orchestrating the gene network governing $\beta$-cell mass expansion and survival under both physiological and pathophysiological conditions.

\section{Defining the regenerative unit of the pancreatic islet: the $\beta$-cell at centre stage}

The search for the regenerative $\beta$-cell or precursor pool that responds to metabolic demands has proved more challenging and controversial than anticipated (Bock 2004, Bonner-Weir et al. 2004, Bonner-Weir \& Sharma 2006). Indeed, depending on the experimental model and degree of injury inflicted to the pancreas, new $\beta$-cells were shown to be generated by neogenesis of ductal epithelium cells (Peshavaria et al. 2006), by transdifferentiation of acinar cells (Lipsett \& Finegood 2002, Minami et al. 2005) and from intra-islet nestinpositive precursor cells (Zulewski et al. 2001). Bone marrow stem cells also appear to indirectly contribute to islet regeneration by promoting proliferation of resident islet cells (Ianus et al. 2003, Hasegawa et al. 2007). Alternatively, lineage-tracing studies elegantly demonstrated that pre-existing mouse adult pancreatic $\beta$-cells, rather than specialized progenitors, were the major source of new insulin-producing cells during adult life and after pancreatectomy (Dor et al. 2004, Nir et al. 2007, Teta et al. 2007). Furthermore, it was recently reported that all $\beta$-cells contributed equally to islet growth and maintenance (Brennand et al. 2007). Thus, similar to other organs such as the liver, all of the aforementioned sources most likely contribute to regeneration according to the severity of the injury (Corcelle et al. 2006). However, new evidence showing sustained $\beta$-cell apoptosis in human patients with longstanding type 1 diabetes along with the demonstration of $\beta$-cell mitogenesis in a diagnosed type 1 diabetic patient clearly argues in favour of $\beta$-cell replication as the predominant mechanism of in vivo islet regeneration in humans (Meier et al. 2005, 2006b). Consistent with this premise, $\beta$-cell proliferation was observed in the vicinity of intrapancreatic gastrinomas in humans (Meier et al. 2006a). Therefore, harnessing key regulatory factors responsible for mature $\beta$-cell replication would certainly facilitate development of a regenerative therapy for the treatment of diabetes.

\section{Pax4 as a master regulator of islet development}

Pax genes encode a family of transcription factors that are key regulators of tissue development and cellular differentiation in embryos acting to promote cell proliferation, migration and survival. Pax proteins comprise nine members divided into four groups based on the specific assembly of three structural domains: the paired domain, the homeodomain and the octapeptide (Lang et al. 2007). DNA binding activity is conferred by either the paired or homeodomain. Pax6 and Pax4, which form subgroup IV characterized by the absence of the octapeptide, are predominantly expressed in the pancreatic islet as well as in the central nervous system for Pax6. Pax4 was shown to be essential for the generation of islet cell progenitors and subsequent $\beta$ - and somatostatinproducing $\delta$-cell maturation, while Pax6 was found to be crucial for $\alpha$-cell fate lineage during embryogenesis (Sosa-Pineda et al. 1997, St-Onge et al. 1997, Greenwood et al. 2006). Interestingly, Pax4 expression is predominantly restricted to $\beta$ - and $\delta$-cells, whereas Pax6 is ubiquitously expressed in all islet cell types (Sosa-Pineda et al. 1997, St-Onge et al. 1997). During development, the 
Pax4 transcript is initially detected in the pancreatic bud at embryonic day (E) 9.5, becoming maximal at E13.5-15.5 and thereafter declining to low expression levels. Lineagetracing studies performed on transgenic mice bearing a pax4 promoter/cre recombinase gene DNA cassette confirmed confinement of the Pax4 expression domain exclusively to endocrine cells of the islets (Greenwood et al. 2006). Consistent with its tissue and cell-specific expression pattern, targeted disruption of the pax4 gene in mice results in the absence of mature $\beta$-and $\delta$-cells with a commensurate increase in the $\alpha$-cells (Sosa-Pineda et al. 1997, Wang et al. 2004). This increase was attributed to the $\alpha$-cell-specific transcription factor Arx that is repressed by Pax4 during development (Collombat et al. 2003, 2005). Substantiating the latter finding, conditional expression of Arx in either embryonic or adult $\beta$-cells was recently found to convert $\beta$-cells into $\alpha$-and pancreatic polypeptide (PP)-producing cells (Collombat et al. 2007). In mouse mutant Pax 4 embryos, scattered insulin-staining cells are apparent at early stages of development (E8.5-9), indicating that Pax4 expression is most likely not mandatory for the generation of $\beta$-cell precursors. However, the strong induction of pax4 gene expression between E13.5 and E15.5 indicates that Pax4 is critical for sustaining the phenotype as well as the proliferation and/or survival of these early committed insulinproducing cells (Sosa-Pineda et al. 1997). Consistent with this premise, the time interval between E13.5 and E15.5 corresponds to a period of massive proliferation and differentiation of $\beta$-cells, the so-called secondary transition phase (Pictet \& Rutter 1972).

\section{Pax4 as a key player coordinating mature islet $\beta$-cell plasticity}

Expression of Pax4 in mature islets has been a matter of debate nourished by the inability to detect low endogenous transcript levels as well as the lack of specific antibodies (Sosa-Pineda et al. 1997, Smith et al. 1999, 2000). The failure to generate Pax4 antibodies most likely stems from its high homology to other Pax members, rendering it difficult to delineate specific antigenic peptide to Pax4. However, novel approaches in antibody production may provide a means to circumvent this caveat in the close future. Nonetheless, recent studies, including ours, have provided evidence for the expression of the Pax4 transcript in adult human, rat and mouse pancreatic islets (Zhang et al. 2001, Heremans et al. 2002, Kojima et al. 2003, Zalzman et al. 2003, Brun et al. 2004, Theis et al. 2004). Furthermore, several human genetic studies have highlighted the importance of Pax4 on islet physiology (Table 1). Indeed, mutations in the pax4 gene were shown to be associated with type 2 diabetes in the Japanese population as well as in Afro-Americans (Shimajiri et al. 2001, 2003, Kanatsuka et al. 2002, Mauvais-Jarvis et al. 2004, Tokuyama et al. 2006). More recently, two mutations in Pax4 were also linked to a subform of type 2 diabetes, maturity onset diabetes of the young (MODY) in the Thai population (Plengvidhya et al. 2007). In addition, two haplotypes of Pax4 have been correlated with type 1 diabetes in Scandinavian families (Holm et al. 2004). Consistent with the latter, an independent study identified two variants of the pax4 gene that were differentially distributed among normal individuals and type 1 diabetic children in the Swiss and German populations. The Pax4C variant was frequent in type 1 diabetic children $(73 \%)$ and rare in the control population $(32 \%)$. In contrast, the heterozygote $\mathrm{Pax} 4 \mathrm{~A} / \mathrm{C}$ combination was prevalent in controls $(62 \%)$ and in islet antibody-positive subjects $(73.6 \%)$ that did not develop diabetes but rare in patients that became diabetic (17.5\%; Biason-Lauber et al. 2005). However, no correlation between this polymorphism and type 1 diabetes could be established in Finnish, Hungarian and UK populations (Hermann et al. 2005, Martin et al. 2006). Discrepancies in these studies most likely arise from genetic heterogeneity or population differences in gene-gene as well as gene-environment interactions. As the common denominator between type 1 and type 2 diabetes is a gradual destruction of $\beta$-cells, we have recently proposed the working hypothesis that Pax4 is likely critical for the expansion as well as the survival of $\beta$-cell mass. Dysfunction in the pax4 gene during

Table 1 Mutations and polymorphisms in the paired box4 (pax4) genes that are associated with diabetes in specific populations

Diabetic phenotype

$\begin{array}{ll}\text { Nucleotide change }^{a} & \\ \text { C109T } & \text { Ketosis-prone diabetes } \\ \text { C363T } & \text { Type 2 } \\ \text { C397T } & \text { Ketosis-prone diabetes } \\ \text { C492T } & \text { Type 2, MODY } \\ \text { A1168C } & \text { Type 1 } \\ \text { Nucleotide 1 (intron 7) G/A } & \text { Type 2, MODY }\end{array}$

Population

Afro-American
Japanese
Afro-American
Thai
Swiss/German
Thai

Afro-American

Afro-American

Swiss/German
Reference

Mauvais-Jarvis et al. (2004)

Shimajiri et al. (2001, 2003)

Mauvais-Jarvis et al. (2004)

Plengvidhya et al. (2007)

Biason-Lauber et al. (2005)

Plengvidhya et al. (2007)

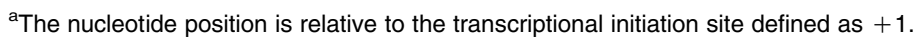


development and/or in mature islets would contribute to increased susceptibility to apoptosis coincident with decreased cell proliferation leading to a gradual loss of $\beta$-cells and ultimately to diabetes in adulthood.

To understand the mechanisms that control pax4 gene expression and thereby impacting its function in mature $\beta$-cells, several studies have mapped and characterized the regulatory regions of both the human and mouse pax4 genes (Smith et al. 2000, Xu \& Murphy 2000, Brink et al. 2001). Sequence deletion analysis revealed that the optimal mouse pax4 gene promoter region required for pancreatic islet expression was found within the first $400 \mathrm{bp}$ upstream of the transcription initiation site. This region shares $88 \%$ similarity with the human sequence (Brink et al. 2001, Brink \& Gruss 2003). Pax4 expression was shown to be dependent on the concerted action of the key pancreatic transcription factors Pan1, Beta2/ NeuroD, hepatic nuclear factor (HNF)-1 $\alpha$, HNF-4 $\alpha$, pancreatic duodenal homeobox (Pdx) 1 and E47/E12 interacting with the proximal promoter (Smith et al. 2000, 2004, Kanno et al. 2006). A further increase in transcription was observed when Beta2/NeuroD was substituted by the early pancreatic committing transcription factor Ngn3 (Smith et al. 2000, 2004). The action of Beta2/NeuroD, HNF-1 $\alpha$, HNF-4 $\alpha$ and Pdx 1 on Pax 4 gene expression is interesting, as mutations in these transcription factors have been associated with MODY (Hani et al. 1999, Fajans et al. 2001, Love-Gregory et al. 2004). Thus, Pax4 may participate as a downstream target of these diabetes-linked transcription factors and most likely aggravates the MODY phenotype by its inability to promote cell replication and to protect against apoptosis.

Evidence for the implication of Pax 4 in $\beta$-cell adaptation in response to physiological cues emerges from studies performed with the proinflammatory cytokine interleukin (IL)-1 $\beta$. Indeed, low concentration of IL-1 $\beta$ stimulates pax4 gene expression, correlating with increased human $\beta$-cell proliferation induced by the cytokine. In contrast, higher concentrations inhibited Pax4 mRNA levels with a concomitant increase in apoptosis (Maedler et al. 2006). This bimodal effect was shown to involve the Fas signalling pathway, which can switch from a mitogenic signal to induction of apoptosis when the FLICE-inhibitory protein (FLIP) is inactive (Maedler et al. 2006). This pathway was also found to be important in sustaining the secretory function of $\beta$-cells, as Fas-deficient mice exhibited impaired glucose-induced insulin secretion (Schumann et al. 2007). It would therefore appear that Pax4 is an integrated factor of the Fas/FLIP signal transduction pathway, which relays either the positive or negative effects of IL-1 $\beta$ pending levels of the cytokine. The latter most likely mimics the in vivo conditions observed in both type 1 and type 2 diabetic patients (Donath \& Halban 2004). More recently, the cytokine ciliary neurotrophic factor was also found to significantly increase Pax 4 mRNA levels and to promote the survival of neonatal rat islets (Rezende et al. 2007), substantiating the notion that Pax4 is an important mediator of cytokine signalling pathways and a regulator of $\beta$-cell plasticity in mature islets.

Consistent with this premise, we previously demonstrated that Pax 4 is indeed a key regulator of $\beta$-cell mass (Brun et al. 2004). We found that activin A and betacellulin stimulated pax4 gene expression with a concomitant increase in rat islet $\beta$-cell replication. Wortmannin suppressed betacellulin-induced Pax4 expression, implicating the PI3 kinase signalling pathway. Our results corroborated previous studies demonstrating that activin A could induce pax4 gene expression in pancreatic cell lines (Ueda 2000) and stimulate growth and differentiation of human foetal pancreatic cells in combination with betacellulin (Demeterco et al. 2000). Furthermore, endogenous Pax4 mRNA levels were also induced in human islets by glucose, activin $\mathrm{A}$ and betacellulin. In addition, the incretin glucagon-like peptide (GLP)-1, a new therapeutic agent for the treatment of diabetes, which has been shown to increase $\beta$-cell mass in mouse and rat pancreas (Xu et al. 1999, Stoffers et al. 2000), also induced Pax4 expression in human islets in the presence of glucose (Brun et al. In press). Overexpression of mouse Pax $4(\mathrm{mPax} 4)$ in rat islets resulted in the induction of the c-myc/Id2 proliferation pathway and of the anti apoptotic gene $b c l-x l$. Two independent studies have demonstrated that forced expression of c-myc requires concomitant induction of $\mathrm{Bcl}-\mathrm{xL}$ to promote $\beta$-cell proliferation rather than apoptosis (Pelengaris et al. 2002, Cheung et al. 2004). Taken together, these studies suggest that $\operatorname{Pax} 4$ coordinates the activation of both genes in order to promote cell survival and mitogenesis (Fig. 1). Overexpression of $\mathrm{mPax} 4$ in human islets also induced proliferation and conferred protection against cytokine-mediated apoptosis, whereas the diabetes-linked mutant identified in the Japanese population (R121W; Shimajiri et al. 2001) was less efficient (Brun et al. 2004). An elegant study recently demonstrated that the mouse Pax 4 protein could permeate islet cells as well as Min6 cells through a novel protein transduction domain located in the paired domain and confer protection against tumour necrosis factor $\alpha$-induced apoptosis. Furthermore, both c-myc and Bcl-xL expression were increased in transduced cells, indicating that similar proliferative and survival pathways are implicated in both rodent and human islets ( $\mathrm{Lu}$ et al. 2007). These studies pave the way to exciting new therapeutic strategies using Pax4 transduction to improve islet cell survival in culture prior to transplantation in type 1 diabetic patients (Shapiro et al. 2006). However, an immediate challenge is to identify additional downstream Pax 4 target genes that may also prove useful for therapeutics. 


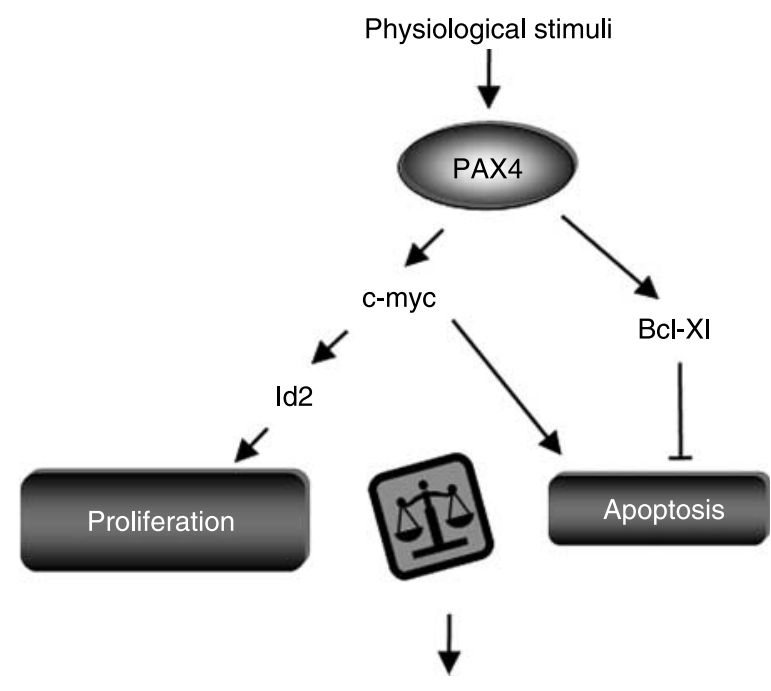

Increased $\beta$-cell mass

Figure 1 Pax4 controls the expression of the c-myc/ld2 proliferation pathway as well as the expression of the antiapoptotic gene $b c l-x l$. Physiological cues activate Pax4, which will then increase c-myc and $\mathrm{Bcl}-\mathrm{xL}$ gene transcription. c-myc will promote id2 gene expression and activate the cell-cycle replication programme. $\mathrm{Bcl}-\mathrm{xL}$-increased expression will promote survival by preventing mitochondria from initiating the apoptotic programme.

\section{Pax4 as an oncogene}

Pax gene family members have also been associated with cancer development (Robson et al. 2006). Consistent with the latter, elevated expression levels of Pax4 are found in both human and rat insulinomas when compared with mature $\beta$-cells (Miyamoto et al. 2001, Brun et al. 2007). Furthermore, a novel Pax4 spliced variant, lacking the carboxy-terminal (Cterminal) end of the protein involved in mediating repression of gene transcription, was also identified in human insulinomas (Miyamoto et al. 2001). Ablation of this C-terminal end may therefore confer tumorigenicity. In contrast, its presence may result in the interaction with cofactors and/or post-translational modifications of Pax4 that limit cell proliferation. Precedents for this premise were demonstrated for other Pax proteins such as Pax3, 5 and 8 that interact with the tumour suppressor $\mathrm{pRb}$ and regulate cell cycle (Buckingham \& Relaix 2007). To address the potential oncogenic function of $\mathrm{Pax} 4$, the latter was suppressed by RNA interference in the insulinoma INS-1E cell line. Inhibition of Pax4 provoked spontaneous apoptosis and further sensitized cells to cytokine-mediated cell death without altering cell proliferation, suggesting that the transcription factor acts as a survival gene rather than promoting replication in this cell line (Brun et al. 2007). The latter study highlights potential pitfalls of using transformed cell lines to delineate the functional role of factors implicated in the regulation of cell replication and apoptosis. Further evidence for the potential mitogenic function of Pax4 in $\beta$-cells was provided by the recent discovery that primary lymphoma and haematologic malignancies expressed high levels of Pax4 that correlated with tumorigenesis. Aberrant expression of the transcription factor in these cells which normally do not express Pax4 was caused by the demethylation of $\mathrm{CpG}$ islands with subsequent promoter activation ( $\mathrm{Li}$ et al. 2006). Accordingly, we have recently demonstrated that similar epigenetic modifications are imposed on the pax4 gene in mature pancreatic islets, thus refraining high expression levels when compared with INS-1E cells (Brun et al. In press). Perturbation in the expression of other closely related members of the Pax family can also lead to cancer (Robson et al. 2006). Increased levels of Pax3 were observed in human tumours of neural crest origin, while Pax2 expression was shown to be indispensable for survival of ovarian and bladder cancer cell lines (Muratovska et al. 2003, Parker et al. 2004). Pax5 was also identified as a key factor for the maintenance of the tumorigenic phenotype of neuroblastoma (Baumann Kubetzko et al. 2004). Similar to Pax4, suppression of Pax2 or Pax7 in tumour cell lines resulted in programmed cell death (Margue et al. 2000, Muratovska et al. 2003). Pax4 may thus qualify as a potential oncogene joining other Pax family members as an important transcriptional regulator involved in development and cancer (Robson et al. 2006).

\section{Conclusion: Pax4 a gene of all trades in islet plasticity}

The alarming spread of obesity worldwide has entailed a dramatic increase in type 2 diabetes. The mechanism is considered to involve inadequate insulin secretion to meet increasing insulin requirements due to obesityrelated resistance to the hormone in the subgroup of individual with inherited susceptibility for type 2 diabetes. The genetic defects are thought to include inappropriate $\beta$-cell proliferative capacity and increased susceptibility to apoptosis. Insufficient regeneration of destroyed $\beta$-cells in the autoimmune process of type 1 diabetes may also be determined by genetic predisposition. The transcription factor Pax 4 could be a common denominator of $\beta$-cell growth and survival in the two diabetic conditions. Accordingly, we would like to propose the working model outlined in Fig. 2 to integrate the various functions that $\mathrm{Pax} 4$ may have on $\beta$-cell physiology and pathophysiology (Fig. 2). Under physiological conditions in which $\beta$-cell mass is called upon to compensate for increasing insulin demands such as in pregnancy or obesity, Pax4 acts as an adaptive gene that permits $\beta$-cell replication. In contrast, 


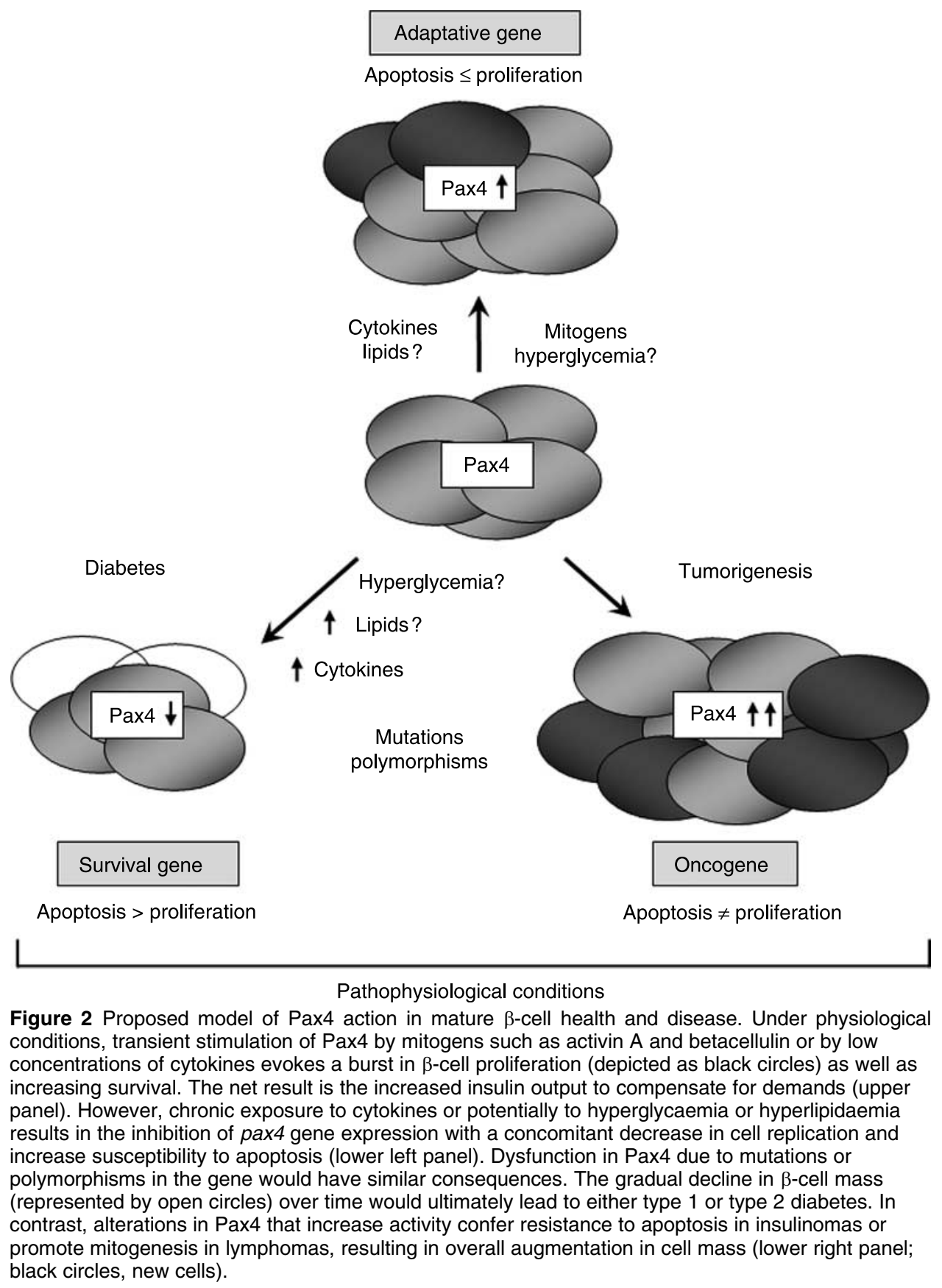

mutations and polymorphisms that weaken Pax4 transcriptional activity would initially contribute to reduction in $\beta$-cell survival and/or proliferation during pancreatic development. Subsequently, the inability of $\beta$-cells to be replenished in mature islets coincident with unabated apoptosis would result in the gradual loss of insulin-producing cells. This will cause relative insulin deficiency, hyperglycaemia and ultimately diabetes. Therefore, Pax4 would qualify as a survival gene. In contrast, gain-of-function mutations conferring resistance against apoptosis would provide a selective advantage for tumour development. In these circumstances, Pax 4 would be considered an oncogene. Validation of this working model will ultimately require the generation of transgenic mice that can specifically and conditionally express either Pax4 wild-type or diabetes-associated variants in islet $\beta$-cells. 


\section{Acknowledgements}

We would like to acknowledge past and present members of the laboratory as well as the numerous collaborators who have contributed to the achievement of these studies. Special thanks to Drs K Maedler, M Donath, B Thorens, P Halban and A Lauber-Biason for their fruitful discussion. We are indebted to Professor Claes B Wollheim (C B W) for his guidance and support in this project. This work was funded by the Swiss National Science Foundation (\#3100A0-107682/1 to B R G). The authors declare that there is no conflict of interest that would prejudice the impartiality of this scientific work.

\section{References}

Baumann Kubetzko FB, Di Paolo C, Maag C, Meier R, Schafer BW, Betts DR, Stahel RA \& Himmelmann A 2004 The PAX5 oncogene is expressed in N-type neuroblastoma cells and increases tumorigenicity of a S-type cell line. Carcinogenesis 25 1839-1846.

Bell GI \& Polonsky KS 2001 Diabetes mellitus and genetically programmed defects in $\beta$-cell function. Nature 414 788-791.

Biason-Lauber A, Boehm B, Lang-Muritano M, Gauthier BR, Brun T, Wollheim CB \& Schoenle EJ 2005 Association of childhood diabetes mellitus with a genomic variant of Pax4: possible link to $\beta$ cell regenerative capacity. Diabetologia 48 900-905.

Bock T 2004 The source(s) for new pancreatic $\beta$ cells in adult life. BioEssays 26 1156-1159.

Bock T, Pakkenberg B \& Buschard K 2003 Increased islet volume but unchanged islet number in ob/ob mice. Diabetes 52 1716-1722.

Bonfanti R, Bognetti E, Meschi F, Brunelli A, Riva MC, Pastore MR, Calori G \& Chiumello G 1998 Residual $\beta$-cell function and spontaneous clinical remission in type 1 diabetes mellitus: the role of puberty. Acta Diabetologica 35 91-95.

Bonner-Weir S \& Sharma A 2006 Are there pancreatic progenitor cells from which new islets form after birth? Nature Clinical Practice. Endocrinology and Metabolism 2 240-241.

Bonner-Weir S, Toschi E, Inada A, Reitz P, Fonseca SY, Aye T \& Sharma A 2004 The pancreatic ductal epithelium serves as a potential pool of progenitor cells. Pediatric Diabetes 5 16-22.

Brelje TC, Scharp DW, Lacy PE, Ogren L, Talamantes F, Robertson M, Friesen HG \& Sorenson RL 1993 Effect of homologous placental lactogens, prolactins, and growth hormones on islet B-cell division and insulin secretion in rat, mouse, and human islets: implication for placental lactogen regulation of islet function during pregnancy. Endocrinology 132 879-887.

Brennand K. Huangfu D \& Melton D 2007 All $\beta$ cells contribute equally to islet growth and maintenance. PLoS Biology 5 1520-1529.

Brink C \& Gruss P 2003 DNA sequence motifs conserved in endocrine promoters are essential for Pax4 expression. Developmental Dynamics 228 617-622.

Brink C, Chowdhury K \& Gruss P 2001 Pax4 regulatory elements mediate beta cell specific expression in the pancreas. Mechanisms of Development 100 37-43.

Brun T, Franklin I, St-Onge L, Biason-Lauber A, Schoenle E, Wollheim CB \& Gauthier BR 2004 The diabetes-linked transcription factor Pax4 promotes $\beta$-cell proliferation and survival in rat and human islets. Journal of Cell Biology 167 1123-1135.

Brun T, Duhamel DL, Hu He KH, Wollheim CB \& Gauthier BR 2007 The transcription factor Pax4 acts as a survival gene in the insulinoma INS1E cells. Oncogene 26 4261-4271.

Brun T, Hu He KH, Lupi R, Boehm B, Wojtusciszyn A, Sauter N, Donath M, Marchetti P, Maedler K \& Gauthier BR In press.
The diabetes-linked transcription factor Pax4 is expressed in human pancreatic islets and is activated by mitogens and GLP-1 Human Molecular Genetics In press.

Buckingham M \& Relaix F 2007 The role of Pax genes in the development of tissues and organs: Pax3 and Pax7 regulate muscle progenitor cell functions. Annual Review of Cell and Developmental Biology 23 645-673.

Butler AE, Janson J, Bonner-Weir S, Ritzel R, Rizza RA \& Butler PC $2003 \beta$-cell deficit and increased $\beta$-cell apoptosis in humans with type 2 diabetes. Diabetes 52 102-110.

Cheung WC, Kim JS, Linden M, Peng L, Van Ness B, Polakiewicz RD \& Janz S 2004 Novel targeted deregulation of c-Myc cooperates with $\mathrm{Bcl}-\mathrm{X}(\mathrm{L})$ to cause plasma cell neoplasms in mice. Journal of Clinical Investigation 113 1763-1773.

Collombat P, Mansouri A, Hecksher-Sorensen J, Serup P, Krull J, Gradwohl G \& Gruss P 2003 Opposing actions of Arx and Pax4 in endocrine pancreas development. Genes and Development 17 2591-2603.

Collombat P, Hecksher-Sorensen J, Broccoli V, Krull J, Ponte I, Mundiger T, Smith J, Gruss P, Serup P \& Mansouri A 2005 The simultaneous loss of Arx and Pax 4 genes promotes a somatostatin-producing cell fate specification at the expense of the $\alpha$ - and $\beta$-cell lineages in the mouse endocrine pancreas. Development 132 2969-2980.

Collombat P, Hecksher-Sorensen J, Krull J, Berger J, Riedel D, Herrera PL, Serup P \& Mansouri A 2007 Embryonic endocrine pancreas and mature $\beta$ cells acquire $\alpha$ and PP cell phenotypes upon Arx misexpression. Journal of Clinical Investigation 117 961-970.

Corcelle V, Stieger B, Gjinovci A, Wollheim CB \& Gauthier BR 2006 Characterization of two distinct liver progenitor cell subpopulations of haematopoietic and hepatic origins. Experimental Cell Research 312 2826-2836.

Demeterco C, Beattie GM, Dib SA, Lopez AD \& Hayek A 2000 A role for activin A and betacellulin in human fetal pancreatic cell differentiation and growth. Journal of Clinical Endocrinology and Metabolism 85 3892-3896.

Donath MY \& Halban PA 2004 Decreased $\beta$-cell mass in diabetes: significance, mechanisms and therapeutic implications. Diabetologia 47 581-589.

Dor Y, Brown J, Martinez OI \& Melton DA 2004 Adult pancreatic $\beta$-cells are formed by self-duplication rather than stem-cell differentiation. Nature 429 41-46.

Expert Committee on the Diagnosis and Classification of Diabetes Mellitus 2003 Report of the expert committee on the diagnosis and classification of diabetes mellitus. Diabetes Care 26 S5-S20.

Fajans SS, Bell GI \& Polonsky KS 2001 Molecular mechanisms and clinical pathophysiology of maturity-onset diabetes of the young. New England Journal of Medicine 345 971-980.

Greenwood AL, Li S, Jones K \& Melton DA 2006 Notch signaling reveals developmental plasticity of $\operatorname{Pax} 4(+)$ pancreatic endocrine progenitors and shunts them to a duct fate. Mechanisms of Development 124 97-107.

Hani EH, Stoffers DA, Chevre JC, Durand E, Stanojevic V, Dina C, Habener JF \& Froguel P 1999 Defective mutations in the insulin promoter factor-1 (IPF-1) gene in late-onset type 2 diabetes mellitus. Journal of Clinical Investigation 104 R41-R48.

Hasegawa Y, Ogihara T, Yamada T, Ishigaki Y, Imai J, Uno K, Gao J, Kaneko K, Ishihara H, Sasano H et al. 2007 Bone marrow (BM) transplantation promotes $\beta$-cell regeneration after acute injury through BM cell mobilization. Endocrinology 148 2006-2015.

Heremans Y, Van De Casteele M, in't Veld P, Gradwohl G, Serup P, Madsen O, Pipeleers D \& Heimberg H 2002 Recapitulation of embryonic neuroendocrine differentiation in adult human pancreatic duct cells expressing neurogenin 3. Journal of Cell Biology 159 303-312.

Hermann R, Mantere J, Lipponen K, Veijola R, Soltesz G, Otonkoski T, Simell O, Knip M \& Ilonen J 2005 Lack of association of PAX4 gene with type 1 diabetes in the Finnish and Hungarian populations. Diabetes 54 2816-2819. 
Holm P, Rydlander B, Luthman H \& Kockum I 2004 Interaction and association analysis of a type 1 diabetes susceptibility locus on chromosome 5q11-q13 and the 7q32 chromosomal region in Scandinavian families. Diabetes 53 1584-1591.

Ianus A, Holz G, Theise N \& Hussain M 2003 In vivo derivation of glucose-competent pancreatic endocrine cells from bone marrow without evidence of cell fusion. Journal of Clinical Investigation 111 843-850.

Kanatsuka A, Tokuyama Y, Nozaki O, Matsui K \& Egashira T $2002 \beta$-cell dysfunction in late-onset diabetic subjects carrying homozygous mutation in transcription factors NeuroD1 and Pax4. Metabolism 51 1161-1165.

Kanno R, Ogihara T, Igarashi Y, Tanaka Y, Smith SB, Kojima I, German MS, Kawamori R \& Watada H 2006 Activin A-induced expression of PAX4 in AR42J-B13 cells involves the increase in transactivation of E47/E12. Biochimica et Biophysica Acta 1759 44-50.

Kashyap S, Belfort R, Gastaldelli A, Pratipanawatr T, Berria R, Pratipanawatr W, Bajaj M, Mandarino L, DeFronzo R \& Cusi K 2003 A sustained increase in plasma free fatty acids impairs insulin secretion in nondiabetic subjects genetically predisposed to develop type 2 diabetes. Diabetes 52 2461-2474.

Kloppel G, Lohr M, Habich K, Oberholzer M \& Heitz PU 1985 Islet pathology and the pathogenesis of type 1 and type 2 diabetes mellitus revisited. Survey and Synthesis of Pathology Research 4 110-125.

Kojima H, Fujimiya M, Matsumura K, Younan P, Imaeda H, Maeda M \& Chan L 2003 NeuroD-betacellulin gene therapy induces islet neogenesis in the liver and reverses diabetes in mice. Nature Medicine 9 596-603.

Lang D, Powell SK, Plummer RS, Young KP \& Ruggeri BA 2007 PAX genes: roles in development, pathophysiology, and cancer. Biochemical Pharmacology 73 1-14.

Li Y, Nagai H, Ohno T, Ohashi H, Murohara T, Saito H \& Kinoshita T 2006 Aberrant DNA demethylation in promoter region and aberrant expression of mRNA of PAX4 gene in hematologic malignancies. Leukemia Research 30 1547-1553.

Lipsett M \& Finegood DT $2002 \beta$-cell neogenesis during prolonged hyperglycemia in rats. Diabetes 51 1834-1841.

Love-Gregory LD, Wasson J, Ma J, Jin CH, Glaser B, Suarez BK \& Permutt MA 2004 A common polymorphism in the upstream promoter region of the hepatocyte nuclear factor- $4 \alpha$ gene on chromosome $20 \mathrm{q}$ is associated with type 2 diabetes and appears to contribute to the evidence for linkage in an Ashkenazi Jewish population. Diabetes 53 1134-1140.

Lu J, Li G, Lan MS, Zhang S, Fan W, Wang H \& Lu D 2007 Pax4 paired domain mediates direct protein transduction into mammalian cells. Endocrinology 148 5558-5565.

Maedler K, Schumann DM, Sauter N, Ellingsgaard H, Bosco D, Baertschiger R, Iwakura Y, Oberholzer J, Wollheim CB, Gauthier BR et al. 2006 Low concentration of interleukin-1 $\beta$ induces FLICEinhibitory protein-mediated $\beta$-cell proliferation in human pancreatic islets. Diabetes $\mathbf{5 5} 2713-2722$.

Margue CM, Bernasconi M, Barr FG \& Schafer BW 2000 Transcriptional modulation of the anti-apoptotic protein BCL-XL by the paired box transcription factors PAX3 and PAX3/FKHR. Oncogene 19 2921-2929.

Martin RJ, Savage DA, Carson DJ, Maxwell AP \& Patterson CC 2006 The PAX4 gene variant $\mathrm{A} 1168 \mathrm{C}$ is not associated with early onset type 1 diabetes in a UK population. Diabetic Medicine 23 927-928.

Mauvais-Jarvis F, Smith SB, Le May C, Leal SM, Gautier JF, Molokhia M, Riveline JP, Rajan AS, Kevorkian JP, Zhang S et al. 2004 PAX4 gene variations predispose to ketosis-prone diabetes. Human Molecular Genetics 13 3151-3159.

Meier JJ, Bhushan A, Butler AE, Rizza RA \& Butler PC 2005 Sustained $\beta$ cell apoptosis in patients with long-standing type 1 diabetes: indirect evidence for islet regeneration? Diabetologia 48 2221-2228.

Meier JJ, Butler AE, Galasso R, Rizza RA \& Butler PC $2006 a$ Increased islet $\beta$ cell replication adjacent to intrapancreatic gastrinomas in humans. Diabetologia 49 2689-2696.
Meier JJ, Lin JC, Butler AE, Galasso R, Martinez DS \& Butler PC $2006 b$ Direct evidence of attempted $\beta$ cell regeneration in an 89-year-old patient with recent-onset type 1 diabetes. Diabetologia 49 1838-1844.

Minami K, Okuno M, Miyawaki K, Okumachi A, Ishizaki K, Oyama K, Kawaguchi M, Ishizuka N, Iwanaga T \& Seino S 2005 Lineage tracing and characterization of insulin-secreting cells generated from adult pancreatic acinar cells. PNAS 102 15116-15121.

Miyamoto T, Kakizawa T, Ichikawa K, Nishio S, Kajikawa S \& Hashizume K 2001 Expression of dominant negative form of PAX4 in human insulinoma. Biochemical and Biophysical Research Communications 282 34-40.

Muratovska A, Zhou C, He S, Goodyer P \& Eccles MR 2003 Paired-Box genes are frequently expressed in cancer and often required for cancer cell survival. Oncogene 22 7989-7997.

Nir T, Melton DA \& Dor Y 2007 Recovery from diabetes in mice by $\beta$ cell regeneration. Journal of Clinical Investigation 117 2553-2561.

Parker CJ, Shawcross SG, Li H, Wang QY, Herrington CS, Kumar S, MacKie RM, Prime W, Rennie IG, Sisley K et al. 2004 Expression of PAX 3 alternatively spliced transcripts and identification of two new isoforms in human tumors of neural crest origin. International Journal of Cancer 108 314-320.

Pelengaris S, Khan M \& Evan G 2002 Suppression of Myc-induced apoptosis in $\beta$ cells exposes multiple oncogenic properties of Myc and triggers carcinogenic progression. Cell 109 321-334.

Peshavaria M, Larmie BL, Lausier J, Satish B, Habibovic A, Roskens V, Larock K, Everill B, Leahy JL \& Jetton TL 2006 Regulation of pancreatic $\beta$-cell regeneration in the normoglycemic $60 \%$ partialpancreatectomy mouse. Diabetes 55 3289-3298.

Pictet R \& Rutter WJ 1972 In Development of the Embryonic Endocrine Pancreas, Eds SE Samaras, MA Cissell, K Gerrish, CVE Wright, M Gannon \& R Stein. Washington, DC: American Physiological Society.

Plengvidhya N, Kooptiwut S, Songtawee N, Doi A, Furuta H, Nishi M, Nanjo K, Tantibhedhyangkul W, Boonyasrisawat W, Yenchitsomanus PT et al. 2007 PAX4 mutations in Thais with maturity onset diabetes of the young. Journal of Clinical Endocrinology and Metabolism 92 2821-2826.

Prentki M \& Nolan CJ 2006 Islet $\beta$ cell failure in type 2 diabetes. Journal of Clinical Investigation 116 1802-1812.

Rezende L, Stoppiglia L, Souza KL, Negro A, Langone F \& Boschero A 2007 Ciliary neurotrophic factor promotes survival of neonatal rat islets via the BCL-2 anti-apoptotic pathway. Journal of Endocrinology 195 157-165.

Robson EJ, He SJ \& Eccles MR 2006 A PANorama of PAX genes in cancer and development. Nature Reviews. Cancer 6 52-62.

Saltiel AR \& Kahn CR 2001 Insulin signalling and the regulation of glucose and lipid metabolism. Nature 414 799-806.

Scaglia L, Smith FE \& Bonner-Weir S 1995 Apoptosis contributes to the involution of $\beta$ cell mass in the post partum rat pancreas. Endocrinology 136 5461-5468.

Schumann DM, Maedler K, Franklin I, Konrad D, Storling J, Boni-Schnetzler M, Gjinovci A, Kurrer MO, Gauthier BR, Bosco D et al. 2007 The Fas pathway is involved in pancreatic $\beta$ cell secretory function. PNAS 104 2861-2866.

Shaat N \& Groop L 2007 Genetics of gestational diabetes mellitus. Current Medicinal Chemistry 14 569-583.

Shapiro AM, Ricordi C, Hering BJ, Auchincloss H, Lindblad R, Robertson RP, Secchi A, Brendel MD, Berney T, Brennan DC et al. 2006 International trial of the Edmonton protocol for islet transplantation. New England Journal of Medicine 355 1318-1330.

Shimajiri Y, Sanke T, Furuta H, Hanabusa T, Nakagawa T, Fujitani Y, Kajimoto Y, Takasu N \& Nanjo K 2001 A missense mutation of Pax4 gene (R121W) is associated with type 2 diabetes in Japanese. Diabetes 50 2864-2869.

Shimajiri Y, Shimabukuro M, Tomoyose T, Yogi H, Komiya I \& Takasu N 2003 PAX4 mutation (R121W) as a prodiabetic variant in Okinawans. Biochemical and Biophysical Research Communications 302 342-344. 
Smith S, Ee H, Conners J \& German M 1999 Paired-homeodomain transcription factor PAX4 acts as a transcriptional repressor in early pancreatic development. Molecular and Cellular Biology 19 8272-8280.

Smith SB, Watada H, Scheel DW, Mrejen C \& German MS 2000 Autoregulation and maturity onset diabetes of the young transcription factors control the human PAX4 promoter. Journal of Biological Chemistry 275 36910-36919.

Smith SB, Watada H \& German MS 2004 Neurogenin3 activates the islet differentiation program while repressing its own expression. Molecular Endocrinology 18 142-149.

Sorenson RL \& Brelje TC 1997 Adaptation of islets of Langerhans to pregnancy: $\beta$-cell growth, enhanced insulin secretion and the role of lactogenic hormones. Hormone and Metabolic Research 29 301-307.

Sosa-Pineda B, Chowdhury K, Torres M, Oliver G \& Gruss P 1997 The Pax4 gene is essential for differentiation of insulin-producing $\beta$ cells in the mammalian pancreas. Nature 386 399-402.

Stoffers DA, Kieffer TJ, Hussain MA, Drucker DJ, Bonner-Weir S, Habener JF \& Egan JM 2000 Insulinotropic glucagon-like peptide 1 agonists stimulate expression of homeodomain protein IDX-1 and increase islet size in mouse pancreas. Diabetes 49 741-748.

St-Onge L, Sosa-Pineda B, Chowdhury K, Mansouri A \& Gruss P 1997 Pax6 is required for differentiation of glucagon-producing $\alpha$-cells in mouse pancreas. Nature 387 406-409.

Stumvoll M, Goldstein BJ \& van Haeften TW 2005 Type 2 diabetes: principles of pathogenesis and therapy. Lancet 365 1333-1346.

Teta M, Rankin MM, Long SY, Stein GM \& Kushner JA 2007 Growth and regeneration of adult $\beta$ cells does not involve specialized progenitors. Developmental Cell 12 817-826.

Theis M, Mas C, Doring B, Degen J, Brink C, Caille D, Charollais A, Kruger O, Plum A, Nepote V et al. 2004 Replacement by a lacZ reporter gene assigns mouse connexin 36,45 and 43 to distinct cell types in pancreatic islets. Experimental Cell Research 294 18-29.

Tokuyama Y, Matsui K, Ishizuka T, Egashira T \& Kanatsuka A 2006 The Arg121Trp variant in PAX4 gene is associated with $\beta$-cell dysfunction in Japanese subjects with type 2 diabetes mellitus. Metabolism 55 213-216.
Ueda Y 2000 Activin A increases Pax4 gene expression in pancreatic $\beta$ cell lines. FEBS Letters 480 101-105.

Unger RH 2005 Longevity, lipotoxicity and leptin: the adipocyte defense against feasting and famine. Biochimie 87 57-64.

Wang J, Elghazi L, Parker SE, Kizilocak H, Asano M, Sussel L \& SosaPineda B 2004 The concerted activities of Pax4 and Nkx2.2 are essential to initiate pancreatic $\beta$-cell differentiation. Developmental Biology 266 178-189.

Xu W \& Murphy L 2000 Cloning of the mouse Pax4 gene promoter and identification of a pancreatic $\beta$ cell specific enhancer. Molecular and Cellular Endocrinology 170 79-89.

Xu G, Stoffers DA, Habener JF \& Bonner-Weir S 1999 Exendin-4 stimulates both $\beta$-cell replication and neogenesis, resulting in increased $\beta$-cell mass and improved glucose tolerance in diabetic rats. Diabetes 48 2270-2276.

Yach D, Stuckler D \& Brownell KD 2006 Epidemiologic and economic consequences of the global epidemics of obesity and diabetes. Nature Medicine 12 62-66.

Zalzman M, Gupta S, Giri RK, Berkovich I, Sappal BS, Karnieli O, Zern MA, Fleischer N \& Efrat S 2003 Reversal of hyperglycemia in mice by using human expandable insulin-producing cells differentiated from fetal liver progenitor cells. PNAS $\mathbf{1 0 0}$ 2426-2431.

Zhang YQ Mashima H \& Kojima I 2001 Changes in the expression of transcription factors in pancreatic AR42J cells during differentiation into insulin-producing cells. Diabetes 50 S10-S14.

Zulewski H, Abraham E, Gerlach M, Daniel P, Moritz W, Muller B, Vallejo M, Thomas M \& Habener J 2001 Multipotential nestinpositive stem cells isolated from adult pancreatic islets differentiate ex vivo into pancreatic endocrine, exocrine, and hepatic phenotypes. Diabetes 50 521-533.

Received in final form 8 November 2007

Accepted 23 November 2007

Made available online as an Accepted Preprint

23 November 2007 